\title{
Analgesic effects of the GIRK Activator, VU0466551, alone and in combination with morphine in acute and persistent pain models
}

\author{
Kristopher K. Abney ${ }^{1}$, Michael Bubser ${ }^{2,3}$, Yu Du$^{2}$, Krystian A. Kozek², Thomas M. Bridges ${ }^{3}$, \\ Craig W. Linsdley ${ }^{2,3}$, J. Scott Daniels ${ }^{4}$, Ryan D. Morrison ${ }^{4}$, Kevin Wickman ${ }^{5}$, Corey R. \\ Hopkins $^{6}$, Carrie K. Jones ${ }^{2,3}$, C. David Weaver ${ }^{2,7}$ \\ ${ }^{1}$ School of Graduate Studies and Research, Meharry Medical College, Nashville, TN 37208, \\ ${ }^{2}$ Vanderbilt Department of Pharmacology, Vanderbilt University School of Medicine, Nashville, TN \\ 37232 , \\ ${ }^{3}$ Vanderbilt Center for Neuroscience Drug Discovery, Nashville, TN 37232 , \\ ${ }^{4}$ Precera Biosciences, Franklin, TN 37067, \\ ${ }^{5}$ Department of Pharmacology, University of Minnesota, Minneapolis, MN 55455, \\ ${ }^{6}$ Department of Pharmaceutical Sciences, College of Pharmacy, University of Nebraska Medical \\ Center, Omaha, NE 68198, \\ ${ }^{7}$ Vanderbilt Institute of Chemical Biology, Nashville, TN 37232
}

\begin{abstract}
G protein-gated inwardly-rectifying potassium (GIRK) channels are potassium-selective ion channels. As their name suggests, GIRK channels are effectors of $\mathrm{G}_{\mathrm{i} / \mathrm{o}} \mathrm{G}$ protein-couple receptors whereby activation of these GPCRs leads to increased GIRK channel activity resulting in decreased cellular excitability. In this way, GIRK channels play diverse roles in physiology as effectors of $\mathrm{G}_{\mathrm{i} / \mathrm{o}^{-}}$-coupled GPCRs: peacemaking in the heart rate, modulation of hormone secretion in endocrine tissues, as well as numerous CNS functions including learning, memory and addiction/reward. Notably, GIRK channels are widely expressed along the spinothalamic tract and are positioned to play roles in both ascending and descending pain pathways. More notably, GIRK channel knockout and knock-down studies have found that GIRK channels play a major role in the


GPCRs (e.g. $\mu$-opioid receptors). Recent advances in GIRK channel pharmacology have led to the development of small molecules that directly and selectively activate GIRK channels. Based on research implicating the involvement of GIRK channels in pain pathways and as effectors of opioid analgesics, we conducted a study to determine whether direct pharmacological activation of GIRK channels could produce analgesic efficacy and/or augment the analgesic efficacy morphine,
\end{abstract}

Author Contributions C.D.W, C.K.J, M.B., K.K.A., C.H. and K.W. conceived and designed the overall study. K.K.A. preformed the thallium flux experiments. J.S.D., R.D.M. and T.M.B. preformed DMPK studies. K.K.A., M.B. and C.K.J. preformed the mouse studies. All authors contributed to experimental analysis, writing, and editing of the manuscript.

Supporting Information Available

The authors declare the following competing financial interests: CDW is an owner of WaveFront Biosciences, the maker of the Panoptic. CDW receives royalties through Vanderbilt University through from the sale of Thallos. 
an opioid receptor agonist capable of activating $\mu$-opioid receptors as well as other opioid receptor subtypes. In the present study, we demonstrate that the small-molecule GIRK activator, VU0466551, has analgesic effects when dosed alone or in combination with sub-maximally effective doses of morphine.

\section{Keywords}

GIRK; Activator; Morphine; Analgesia; Hot Plate; Formalin Assay

G protein-gated inwardly-rectifying potassium (GIRK) channels are potassium $\left(\mathrm{K}^{+}\right)$selective ion channels that are members of the inwardly-rectifying $K^{+}$channels $\left(K_{I R}\right)$ family. 1-2 Activation of GIRK channels by pertussis toxin sensitive $\mathrm{G}_{\mathrm{i} / \mathrm{o}^{-}}$-coupled $\mathrm{G}$ protein-coupled receptors (GPCRs) result in decreased cellular excitability ${ }^{3}$. Both the $\beta \gamma$ subunits of heterotrimeric $\mathrm{G}$ proteins and phosphatidylinositol 4,5-bisphosphate are critical factors in the activation of GIRK channels while internal blockade by magnesium $\left(\mathrm{Mg}^{2+}\right)$ and/or polyamines are responsible for GIRK channels' characteristic inward rectification. ${ }^{1,4-7}$

GIRK channels form tetrameric complexes from four highly homologous subunits, GIRK1GIRK4 (Kir3.1-3.4). While GIRK2 and GIRK4 channels can form functional homomeric channels, GIRK1 and GIRK3 subunits do not appear to form functional homomeric channel complexes. GIRK1 is able to form hetero-tetrameric channels with GIRK2, GIRK3, and GIRK $4 .{ }^{8}$ GIRK channels made up of varying subunit compositions are differentially expressed throughout the body. ${ }^{9}$ For instance, channels composed of GIRK1 and GIRK4 subunits are expressed in the sinoatrial node of the heart where they play a crucial role in pace making. The GIRK1/2 channel subtype is chiefly expressed in the nervous system ${ }^{10}$, and notably along the spinal cord, the superficial layers of the dorsal horn, and the periaqueductal grey, an area associated with analgesia. ${ }^{11}$ While GIRK1-containing GIRK channels dominate expression throughout the body, there are a few distinct cell types which appear to express non-GIRK1-containing GIRKs including the most dopaminergic cells in the ventral tegmental area and substantia nigra which are believed to express GIRK2/3 heterotetrameric and GIRK2 homotetrameric channels, respectively. ${ }^{12-13}$

GIRK channels couple to the $\mu$-opioid receptor $(\mu \mathrm{OR})$, a key target of opioid analgesics, in the superficial layers of the dorsal horn of the spinal cord ${ }^{14-16}$ and numerous lines of evidence indicate that opioid-based therapeutics, such as morphine and fentanyl, harness GIRK channel-mediated hyperpolarization to produce a significant portion of their analgesic

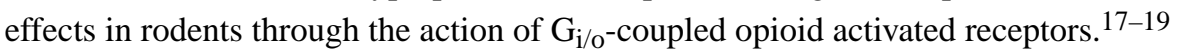
Furthermore, variations in the Girk2 gene, KCNJ6, in humans is associated with decreased therapeutic efficacy of opioid analgesics and pain sensitivity. ${ }^{19-20}$

Recently, development of the direct-acting, selective small-molecule GIRK channel activator, ML297 has opened the door to evaluating the in vivo effects of GIRK channel activation. ${ }^{22}$ Previously we have shown that ML297 can produce anxiolytic effects ${ }^{23}$ and reduced seizure-like activity in mouse models. ${ }^{22}$ Further medicinal chemistry efforts resulted in the development of VU0466551. ${ }^{24}$ This compound is approximately 2-fold more potent than ML29722,24 (Fig 1) and 20\% more efficacious at activating GIRK1/2 channels 
(Table 1s) while retaining the specificity for GIRK1-containing GIRK channels observed for ML297. Due to the superior potency and efficacy of VU0466551 compared to ML297, we chose this compound to further explore the effects of GIRK channel activation on physiological behaviors, particularly with respect to their role in analgesia. To this end, we investigated the in vivo effects of VU0466551 alone or in combination with opioid receptor agonist, morphine, in two preclinical mouse models of acute supraspinal-mediated nociception and persistent pain, specifically the hotplate and formalin tests. ${ }^{25-27}$ Our data demonstrate the ability of pharmacological GIRK activation to produce analgesia and to enhance the analgesic efficacy of sub-maximally effective doses of morphine. These observations suggest the potential for GIRK channels as a target for analgesia and opioidsparing therapeutic approaches which are badly needed in response to the present opioid abuse crisis.

\section{Results and Discussion}

Although GIRK channels have been the target of intense research interest for well over a decade, it was only recently that potent and selective small-molecule activators have become available to the research community. ${ }^{28-29}$ In particular the prototype GIRK channel activator, ML297, is being used by a growing number of investigators to explore the role of GIRK channels in physiology. ${ }^{30-31}$ While ML297 remains a useful tool to study GIRK channels in a variety of settings, for this present study we chose to use VU0466551 (Fig 1). Notably, this compound displays an approximately 2 -fold improved potency compared to ML297, while retaining selectivity for only GIRK1-containing channels ${ }^{29}$. In addition, we explored the selectivity of VU0466551 for a closely related $\mathrm{K}_{\mathrm{ir}}$ family member, $\mathrm{K}_{\mathrm{ir}} 6.1$, other ion channels targeted for analgesia, as well as the $\mu \mathrm{OR}$ itself. We found VU0466551 to be inactive at homomeric GIRK2 channels, $\mathrm{K}_{\mathrm{ir}} 6.1$-containing channels, $\mathrm{K}_{\mathrm{v}} 7.2$ channels. TRPV1 channels, and $\mu \mathrm{OR}$ (Table 1s). We did, however, find that a $10 \mu \mathrm{M}$ concentration of VU0466551 inhibited the activity of $\mathrm{Na}_{\mathrm{v}} 1.7$ channels by approximately $50 \%$. However, VU0466551 still displayed a greater than 140-fold higher potency for GIRK1/2 channels compared to $\mathrm{Na}_{\mathrm{v}} 1.7$ channels. Thus, we believe it unlikely that inhibition of $\mathrm{Na}_{\mathrm{v}} 1.7$ channels plays a role in the analgesic efficacy observed with VU0466551 alone or in combination with morphine.

In order to further evaluate the potential of VU0466551 as an in vivo tool, we first investigated the pharmacokinetic (PK) properties of this compound in vivo after systemic administration in $\mathrm{C} 57 \mathrm{bl} / \mathrm{J} 6$ mice. VU0466551 possessed suitable physiochemical properties to allow formulation in uniform suspensions utilizing $20 \%(\mathrm{w} / \mathrm{v})$ hydroxypropyl- $\beta$ cyclodextrin $(\mathrm{BCD}) /$ water vehicle $(1.5 \mathrm{mg} / \mathrm{mL})$ facilitating dosing up to $30 \mathrm{mg} / \mathrm{kg}$ i.p. As shown in Table 1s, VU0466551 displayed a $\mathrm{T}_{\max }$ of $15 \mathrm{~min}$ and was cleared with a $\mathrm{T}_{1 / 2}$ of $\sim 1$ hour (Table 2s). The total $\mathrm{C}_{\max }$ plasma and brain exposure levels of VU0466551 were $554( \pm 79) \mathrm{ng} / \mathrm{ml}$ and $209( \pm 44) \mathrm{ng} / \mathrm{g}$, respectively (Table 3s). Taking into account in vitro measurements of plasma protein binding $\mathrm{f}_{\mathrm{u} \text {, plasma }} 0.03$ and brain homogenate binding $\mathrm{f}_{\mathrm{u} \text {, brain }} 0.011$, the calculated $\mathrm{K}_{\mathrm{p} \text {,uu }}$ for VU0466551 was 0.14 . Thus, at $\mathrm{T}_{\max }$ the estimated free brain concentration of VU0466551 was $\sim 7 \mathrm{nM}$. Based on the enhanced potency and suitable PK properties of VU0466551 for in vivo dosing, we first systematically evaluated the effects of this compound administered i.p. across a broad range of autonomic and 
somatomotor nervous systems functions ${ }^{32-33}$ using a modified Irwin neurological behavior battery in mice.

As shown in Table 3s, we observed several dose-related changes in the different measurements of the Irwin battery. For example, VU0466551 decreased core body temperature at both the $10 \mathrm{mg} / \mathrm{kg}$ and $30 \mathrm{mg} / \mathrm{kg}$ doses (Table $4 \mathrm{~s}$ ), with sustained effects observed for over 8 hours at the $30 \mathrm{mg} / \mathrm{kg}$ dose. Interestingly, we also observed a doserelated increase in tail erection or "Straub-tail" similar to effects previously reported with $\mu \mathrm{OR}$ agonists. ${ }^{34}$ In addition, modest decreases in pinna reflex, general locomotor output, grasping loss, leg weakness, placing loss, righting loss, and induction of catalepsy were observed at the $30 \mathrm{mg} / \mathrm{kg}$ dose (Table $4 \mathrm{~s}$ ). However, most of these effects resolved after 1 hour and none were evident at the end of the 8 hour test period, with the exception of decreases tail pinch response and escape loss.

Based on these initial behavioral observations with VU0466551, we next conducted studies to further investigate the effects of this compound on locomotor output and measures of acute nociception. Previous studies reported that ML297 produced a substantial decrease in general locomotor activity. ${ }^{22}$ Indeed, we also observed a decrease in motor output when VU0466551 was assessed in the Irwin battery. To more quantitatively evaluate VU0466551 effects on locomotor function and coordination, we utilized the open-field activity and rotarod tests. After pretreatment with 10 or $30 \mathrm{mg} / \mathrm{kg}$ of VU0466551, mice were placed into open field chambers and changes in locomotion were evaluated for a duration of $90 \mathrm{~min}$. As shown in Figure 1s, the $10 \mathrm{mg} / \mathrm{kg}$ dose of VU0466551 did not affect locomotion, while the $30 \mathrm{mg} / \mathrm{kg}$ dose produced a marked increase in locomotor activity in the initial $30 \mathrm{~min}$ of exploratory activity. While the underlying mechanisms for the observed increases in locomotor activity with VU0466551 remain unclear; it is interesting to note that $\mu \mathrm{OR}$ agonists ${ }^{34}$ such as morphine also have been shown to induce similar effects on the motor activity of mice, suggesting that GIRK channel activation may, at least in part, mediate this effect. ${ }^{35}$ To further assess the effects of VU0466551 on motor coordination and balance, we employed the accelerated rotarod test. Following injection of VU0466551 at dosages of $1,3,10$, and $30 \mathrm{mg} / \mathrm{kg}$, we did not observe a decrease in rotarod performance (Figure 2s). Thus, within the dose range tested, VU0466551 did not have a significant effect coordinated balance and motor functions.

Because of the preponderance of data implicating a role for GIRK in the efficacy of opioids ${ }^{14-21,36}$ and the decreased sensitivity we observed in the tail-pinch portion of the Irwin battery, we were interested in determining whether VU0466551 had any effects on acute nociception utilizing the mouse hot plate assay. The mouse hotplate assay is a preclinical model of acute supraspinally mediated nociception in which latency to lick the front or hind paws exposed to a $55^{\circ} \mathrm{C}$ hot plate is recorded. As shown in Figure 2, a 30 $\mathrm{mg} / \mathrm{kg}$ i.p. dose of VU0466551 had no effect on response latency to the hotplate. Whereas, a $30 \mathrm{mg} / \mathrm{kg}$ s.c. dose of morphine produced significant increases in response latency.

We next investigated whether VU0466551 could augment the analgesic efficacy of a submaximally effective dose of morphine in the hotplate assay. First, we evaluated the full doserelated analgesic effects of morphine on latencies to respond in the mouse hot plate assay. 
As shown in Figure 2, morphine produced robust dose-dependent analgesic effects, significant at 10,18 and $30 \mathrm{mg} / \mathrm{kg}$ s.c.

In Figure 2, we observed significant increases in analgesic response for sub-maximally effective doses of morphine in the presence of $30 \mathrm{mg} / \mathrm{kg}$ VU0466551 compared to morphine alone, significant at the morphine doses of 10 and $18 \mathrm{mg} / \mathrm{kg}$. (Figure 2). Thus, although VU0466551 had no effect on acute supraspinal nociception when administered alone, it did appear to augment the analgesic efficacy of sub-maximally effective doses of morphine in the hot plate assay. Next, we evaluated the effects of VU0466551 in a mouse formalin model of persistent pain alone and in combination with sub-maximally effective doses of morphine. Persistent pain states can arise from alterations in sensitivity within both ascending and descending pain pathways in the brain and the spinal cord..$^{25-26}$ The formalin model of persistent pain involves induction of moderate, continuous pain generated by tissue injury from a subcutaneous injection of formalin into the hindpaw of the mouse, resulting in an early and late phase of paw-licking behavior where the late phase is considered to be an index of persistent pain mechanisms including central sensitization. ${ }^{37-39}$ In particular, the resultant state of central sensitization can produce an ongoing condition of spontaneous, persistent pain as well as an increased sensitivity to painful stimuli (hyperalgesia) or to normally nonpainful mechanical or thermal stimuli (allodynia). ${ }^{40}$

In this study, unlike in the effects observed in the hotplate assay, VU0466551 produced a dose-dependent decrease in paw-licking responses consistent with increased analgesia, significance at the $30 \mathrm{mg} / \mathrm{kg}$ doses in both the acute (Fig 3a) and tonic (Fig 3b) phases of the formalin assay. These effects observed with VU0466551 were similar to the dose-related effects of morphine on both the acute and tonic phases of the formalin assay (Fig 3). In addition, enhanced analgesic efficacy was observed during the acute and tonic phases when a $30 \mathrm{mg} / \mathrm{kg}$ dose of VU0466551 was administered in combination with morphine (Fig 3).

In the acute phase, $3 \mathrm{mg} / \mathrm{kg}$ morphine in combination with $30 \mathrm{mg} / \mathrm{kg}$ VU0466551, produced a similar degree of efficacy as the dose of $10 \mathrm{mg} / \mathrm{kg}$ morphine alone. While in the second phase, the addition of $30 \mathrm{mg} / \mathrm{kg}$ VU0466551 to the $1 \mathrm{mg} / \mathrm{kg}$ dose of morphine produced efficacy comparable to the maximally effective dose of $3 \mathrm{mg} / \mathrm{kg}$ morphine when given alone in the tonic phase of the formalin assay.

Because it is critical to be aware of potential of pharmacokinetic drug-drug interactions that might confound the interpretations of the efficacy studies conducted in the hotplate and formalin tests with VU0466551 and morphine in combination, we performed an in vivo exposure study wherein we dosed VU466551 alone, morphine alone, or VU0466551 in combination with morphine. In this study, we did not observe a significant difference in plasma or brain exposure levels for morphine $(18 \mathrm{mg} / \mathrm{kg}$ ) when given with VU0466551 (30 $\mathrm{mg} / \mathrm{kg}$ ) in comparison with exposure levels detected for each compound alone (Table $2 \mathrm{~s}$ ).

Herein we report the investigation of the effects of VU0466551, an ML297 analog, on gross neurological function using a modified Irwin behavioral battery, tests of effects on motor function, and tests in two models of pain. While we observed only modest effects on most neurological functions, we did observe an acute decreased locomotor activity in the Irwin 
evaluation. This loss of activity is consistent with what we previously observed with ML297. Also, as with ML297, at doses resulting in decreased locomotor activity the animals were fully capable of coordinated movement during rotarod assay thus demonstrating that the loss of spontaneous locomotor activity is not the result of an inability to produce coordinated movement. However, with a more careful evaluation of spontaneous locomotor effects using an open field test we found that, at a $30 \mathrm{mg} / \mathrm{kg}$ dose of VU0466551 produced an increase in locomotor activity reminiscent of what has been observed with morphine. While it is intriguing to speculate about potential reasons for the observed increase in spontaneous locomotor activity, further study is needed to gain a broader understanding of the physiological consequences of GIRK channel activation.

In addition to the observed effects on locomotor function, we observed that direct activation of GIRK channel produced analgesic efficacy in two murine models of nociception either alone (formalin assay) or in conjunction with low-dose morphine (hotplate and formalin assays). It is unclear at present why VU0466551 was effective on acute nociception when dosed in the absence of morphine in the formalin assay and not in the hotplate assay. However, these differences may reflect differential sensitivity to thermal versus chemically induced nociception and/or the potential for enhanced effects to supraspinal versus spinalmediated mechanisms of nociception by GIRK1/2 channel activators. As noted previously, GIRK channels are expressed in many types of neurons along the spinothalamic tract. Future studies will focus on gaining a greater understanding of the mechanistic basis of the analgesic efficacy of VU0466551 alone as well as in the presence of morphine. It will also be of great interest to determine the effects of GIRK channel activation in animal models of chronic pain including nerve injury models as well as how GIRK channel activation affects chronic morphine dosing.

While much remains to be investigated regarding the mechanism by which activation of GIRK channels promotes analgesia in the absence or presence of opioids, these findings do suggest that GIRK channel activators may offer an opportunity for non-opioid or opioidsparing, adjuvant therapies.

Finally, because GIRK channels may also be effectors of morphine's addictive properties, it will be important to investigate whether direct GIRK activation alone has any addictive potential. Although our previous studies showing that ML297 was not active in conditioned place preference tests ${ }^{23}$, a more thorough assessment of the effects of GIRK activation on reward and addiction is needed. These studies should assess small molecule-mediate GIRK activation alone as well as in conjunction with morphine and potentially other addictive agents to determine whether direct GIRK1-containing GIRK activation has any effect on their addictive properties.

\section{Methods}

\section{Thallium Flux Assay}

HEK-293 cells (ATCC) stably transfected with GIRK1, 2, were used for thallium $\left(\mathrm{Tl}^{+}\right)$flux assays, GIRK1/2 channel-expressing cells were dislodged from T-175 tissue culture flasks using TrypLE Express (Thermo-Fisher, Waltham, MA), then transferred into a $50 \mathrm{~mL}$ 
conical tube, and centrifuged at $500 \mathrm{~g}$ for $2 \mathrm{~min}$. The supernatant solution was removed and cells were resuspended at a concentration of $\sim 1000$ cell $/ \mu \mathrm{L}$ in a-MEM containing $10 \%(\mathrm{v} / \mathrm{v})$ fetal bovine serum (Thermo-Fisher, Waltham, AM) and 1\% (v/v) GlutaGro (Corning, Corning, NY)). Twenty $\mu \mathrm{L}$ of the cell suspension were plated into amine-coated, clearbottom, and black-walled 384-well plate (cat\# 354719, BD, Franklin Lakes, NJ) using an electronic multichannel pipette. Plates were then cultured overnight at $5 \% \mathrm{CO}_{2}$ in a cellculture incubator at $37^{\circ} \mathrm{C}$. Following overnight incubation, cell-culture medium was removed and replaced with dye-loading assay buffer (Hank's balanced salt solution, $20 \mathrm{mM}$ HEPES containing 0.03\% (w/v) Pluronic F-127 (Sigma-Aldrich, St. Louis, MO) and $1 \mu \mathrm{M}$ $\mathrm{Tl}^{+}$-sensitive dye, Thallos AM (TEFlabs, Austin TX) and incubated for 1 hour at room temperature. After incubation, dye loading solution was removed and replaced with $20 \mathrm{uL} /$ well of assay buffer. The plates were then loaded into a WaveFront Panoptic (Franklin, TN). The data were acquired at $1 \mathrm{~Hz}$ (excitation $480 \pm 20 \mathrm{~nm}$ and emission $540 \pm 20 \mathrm{~nm}$ ) for 10 seconds, then $20 \mathrm{uL} /$ well of GIRK modulators were added (prepared as described below) and incubated for 2 minutes. Following incubation, $10 \mu \mathrm{L} /$ well of $\mathrm{Tl}^{+}$-stimulus buffer $(125 \mathrm{mM}$ NaHCO3, $1.8 \mathrm{mM}$ CaSO4, $1 \mathrm{mM}$ MgSO $4,5 \mathrm{mM}$ glucose, 2 mM Tl $2 \mathrm{SO} 4,10 \mathrm{mM}$ HEPES pH 7.4 all 5-fold higher than their final concentration in the assay) was added and data collection continued for 2 additional minutes. Data were analyzed using Microsoft Excel and potencies were obtained using a four-parameter logistic equation in the Excel add-in, XLfit (IDBS, Surrey, UK). Test compounds were solubilized in DMSO to $30 \mathrm{mM}$, then plated on ECHO-qualified 384-well plates. A 10-point 3-fold serial dilution was achieved using a Echo 555 liquid handler (Labcyte, San Jose, CA) in conjunction with Labcyte's DoseResponse software. Data represent at least 8 independent experiments and all DMSO concentration were $0.3 \%(\mathrm{v} / \mathrm{v})$.

\section{Animal Care and Housing}

All in vivo studies were carried out using adult male wild-type C57BL/6 mice (Jackson Labs) Animals were group-housed under a 12/12-h light-dark cycle (lights on at 6 AM) with food and water available ad libitum. All animal experiments were approved by the Vanderbilt University Animal Care and Use Committee, and experimental procedures conformed to guidelines established by the National Research Council's Guide for the Care and Use of Laboratory Animals. All efforts were made to minimize animal suffering and the number of animals used.

\section{Hot Plate Assay}

The effects of VU0466551 on nociception was tested using a hot plate apparatus (Ugo Basile, Gemonia, Italy) set to a constant temperature of $55^{\circ} \mathrm{C}$. The heating plate $(20 \mathrm{~cm}$ diameter) was surrounded by a restraining cylinder made of Plexiglass. Baseline reactivity to the thermal stimulus was assessed in a pre-test by placing mice on the hot plate and determining the latency to the nociceptive response, such as front or hind paw licking or jumping. If an animal did not exhibit a nociceptive response within $30 \mathrm{~s}$, the animal was removed from the hot plate to avoid tissue damage and returned to its cage. One hour after the baseline test, mice were injected with vehicle or morphine $(1-30 \mathrm{mg} / \mathrm{kg}$, s.c.) followed 15 minutes later by administration of VU0466551 (30 mg/kg, i.p.) or vehicle. Another 15 minutes later, mice were tested on the hot plate again to determine antinociceptive treatment 
effects. Using the response latency from the two tests, the \% maximum possible effect (\%MPE) was calculated as follows: \%MPE = (postdrug latency - predrug latency)/ (maximum latency - predrug latency) $\times 100$. The $\%$ MPE for each treatment was then normalized to the \%MPE obtained with the most efficacious morphine dose $(30 \mathrm{mg} / \mathrm{kg})$. Data were analyzed in GraphPad Prism using ANOVA with post-hoc Dunnett's multiple comparison test. Hotplate assays were conducted in a blinded fashion whereby the experimenter scoring the assay did not know if the animal had been treated with vehicle or, if not, what dose of VU0466551 had been administered.

\section{Formalin Assay}

Mice were placed into clear plastic cylinders for $30 \mathrm{~min}$ before being injected with vehicle or morphine $(1-30 \mathrm{mg} / \mathrm{kg}$, s.c.) followed 15 minutes later by administration of VU0466551 $(30 \mathrm{mg} / \mathrm{kg}$, i.p.) or vehicle. Another 15 minutes later, animals were confined in a restraining tube and $2.5 \%$ formalin solution in $0.9 \%$ saline was injected into the foot pad of the right hind paw. The animals' behavior was video recorded for a total of 60 minutes for subsequent manual scoring of licking responses of the injected hind paw. Licking behavior of the affected paw was scored during the acute phase ( $0-5$ minutes) and the tonic phase (20-30 minutes) of the nociceptive response. Inflammation of the injected paw was confirmed visually, and any animals that did not show inflammation of the injected paw were excluded from the study. Animals were sacrificed immediately after the conclusion of the assay. Data are presented as the duration of licking (mean \pm S.E.M.) and were analyzed in GraphPad Prism using ANOVA with post-hoc Dunnett's multiple comparison test. Formalin assays were conducted in a blinded fashion whereby the experimenter scoring the assay did not know if the animal had been treated with vehicle or, if not, what dose of VU0466551 had been administered.

\section{Supplementary Material}

Refer to Web version on PubMed Central for supplementary material.

\section{Acknowledgements}

The authors acknowledge the Vanderbilt High-throughput Screening Facility and the Vanderbilt Murine Behavioral Facility. The authors also acknowledge Baovi Vo for her helpful comments during the manuscript preparation.

Funding Statement Funding provided for K.K.A. by R25GM059994 to Meharry Medical College and for C.D.W, K.W., C.H. by 5R01MH107399.

\section{References}

1. Yamada M, Inanobe A, and Kurachi Y (1998) G Protein Regulation of Potassium Ion Channels. Pharmacol Rev. 50 (4), 723-757. [PubMed: 9860808]

2. Dascala N, (1997) Signalling Via the G Protein-Activated $K^{+}$Channels. Cell Signal. 9 (8), 551-573. [PubMed: 9429760]

3. Pfaffinger PJ, Martin MJ, Hunter DD, Nathanson NM, and Hille B (1985) GTP-binding proteins couple cardiac muscarinic receptors to a K channel. Nature 317(6037), 536-538. [PubMed: 2413367] 
4. Inanobe A, Morishige KI, Takahashi N, Ito H, Yamada M, Takumi T, Nishina H, Takahashi K, Kanaho Y, Katada T, and Kurachi Y (1995) G $\beta \gamma$ Directly Binds to the Carboxyl Terminus of the G Protein-Gated Muscarinic K+ Channel, GIRK1. Biochem Biophy Res Com. 212 (3), 1022-1028.

5. Huang CL, Slesinger PA, Casey PJ, Jan YN, and Jan LY (1995) Evidence that direct binding of G beta gamma to the GIRK1 $\mathrm{G}$ protein-gated inwardly rectifying $\mathrm{K}^{+}$channel is important for channel activation. Neuron 15 (5), 1133-1143. [PubMed: 7576656]

6. Huang CL, Feng S, and Hilgemann DW (1998) Direct activation of inward rectifier potassium channels by $\mathrm{PIP}_{2}$ and its stabilization by Gbetagamma. Nature 391 (6669), 803-806. [PubMed: 9486652]

7. Zhang H, He C, Yan X, Mirshahi T, and Logothetis DE (1999) Activation of inwardly rectifying $\mathrm{K}^{+}$ channels by distinct PtdIns(4,5)P2 interactions. Nat Cell Biol. 1 (3), 183-188. [PubMed: 10559906]

8. Ma D, Zerangue N, Raab-Graham K, Fried SR, Jan YN, and Jan LY (2002) Diverse Trafficking Patterns Due to Multiple Traffic Motifs in G Protein-Activated Inwardly Rectifying Potassium Channels from Brain and Heart. Neuron 33 (5), 715-729. [PubMed: 11879649]

9. Lüscher C, and Slesinger PA (2010) Emerging concepts for G protein-gated inwardly rectifying potassium (GIRK) channels in health and disease. Nat Rev Neurosci. 11 (5), 301-315. [PubMed: 20389305]

10. Liao YJ, Jan YN, and Jan LY (1996) Heteromultimerization of G-Protein-Gated Inwardly Rectifying $\mathrm{K}^{+}$Channel Proteins GIRK1 and GIRK2 and Their Altered Expression in weaver Brain. J. Neurosci 16 (22), 7137-7150. [PubMed: 8929423]

11. Depaulis A, Morgan MM, and Liebeskind JC (1987) GABAergic modulation of the analgesic effects of morphine microinjected in the ventral periaqueductal gray matter of the rat. Brain Res. 436 (2), 223-228. [PubMed: 3435824]

12. Labouebe G, Lomazzi M, Cruz HG, Creton C, Lujan R, Li M, Yanagawa Y, Obata K, Watanabe M, Wickman K, Boyer SB, Slesinger PA, and Luscher C (2007) RGS2 modulates coupling between GABAB receptors and GIRK channels in dopamine neurons of the ventral tegmental area. Nat Neurosci. 10 (12), 1559-1568. [PubMed: 17965710]

13. Lei Q, Jones MB, Talley EM, Schrier AD, McIntire WE, Garrison JC, and Bayliss DA (2000) Activation and inhibition of $\mathrm{G}$ protein-coupled inwardly rectifying potassium (Kir3) channels by $\mathrm{G}$ protein $\beta \gamma$ subunits. Proc Natl Acad Sci U. S. A 97 (17), 9771-9776. [PubMed: 10944236]

14. Marker CL, Stoffel M, and Wickman K (2004) Spinal G-protein-gated $\mathrm{K}^{+}$channels formed by GIRK1 and GIRK2 subunits modulate thermal nociception and contribute to morphine analgesia. J Neurosci. 24 (11), 2806-2812. [PubMed: 15028774]

15. Matthes HWD, Maldonado R, Simonin F, Valverde O, Slowe S, Kitchen I, Befort K, Dierich A, Le Meur M, Dollé P, Tzavara E, Hanoune J, Roques BP, and Kieffer BL (1996) Loss of morphineinduced analgesia, reward effect and withdrawal symptoms in mice lacking the $\mu$-opioid-receptor gene. Nature 383, 819-823. [PubMed: 8893006]

16. Marker CL, Luján R, Loh HH, and Wickman K (2005) Spinal G-protein-gated potassium channels contribute in a dose-dependent manner to the analgesic effect of mu- and delta- but not kappaopioids. J Neurosci. 25 (14), 3551-3559. [PubMed: 15814785]

17. Ikeda K1, Kobayashi T, Kumanishi T, Niki H, Yano R (2000) Involvement of G-protein-activated inwardly rectifying K (GIRK) channels in opioid-induced analgesia. Neurosci Res. 38(1):113-6. [PubMed: 10997585]

18. Mitrovic I, Margeta-Mitrovic M, Bader S, Stoffel M, Jan LY, Basbaum AI. (2003) Contribution of GIRK2-mediated postsynaptic signaling to opiate and a2-adrenergic analgesia and analgesic sex differences. PNAS. 100:271-276. [PubMed: 12496346]

19. Nockemann D, Rouault M, Labuz D, Hublitz P, McKnelly K, Reis FC, Stein C, Heppenstall PA. (2013) The $\mathrm{K}(+)$ channel GIRK2 is both necessary and sufficient for peripheral opioid-mediated analgesia. EMBO Mol Med. 5(8):1263-77. [PubMed: 23818182]

20. Bruehl S, Denton JS, Lonergan D, Koran ME, Chont M, Sobey C, Fernando S, Bush WS, Mishra P, and Thornton-Wells TA (2013) Associations Between KCNJ6 (GIRK2) Gene Polymorphisms and Pain-Related Phenotypes. Pain 154 (12), 2853-2859. [PubMed: 23994450]

21. Nishizawa D, Fukuda K, Kasai S, Ogai Y, Hasegawa J, Sato N, Yamada H, Tanioka F, Sugimura H, Hayashida M, and Ikeda K (2014) Association between KCNJ6 (GIRK2) gene polymorphism 
rs2835859 and post-operative analgesia, pain sensitivity, and nicotine dependence. J Pharmacol Sci. 126(3), 253-263. [PubMed: 25346042]

22. Kaufmann K, Romaine I, Days E, Pascual C, Malik A, Yang L, Zou B, Du Y, Sliwoski G, Morrison RD, Denton J, Niswender CM, Daniels JS, Sulikowski GA, Xie X, Lindsley CW and Weaver CD (2013) ML297 (VU0456810), the First Potent and Selective Activator of the GIRK Potassium Channel, Displays Antiepileptic Properties in Mice. ACS Chem Neurosci. 4 (9), 1278-1286. [PubMed: 23730969]

23. Wydeven N, Marron FD, Du Y, Benneyworth MA, Hearing MC, Fischer RA, Thomas MJ, Weaver CD, and Wickman K (2014). Mechanisms underlying the activation of G-protein-gated inwardly rectifying K+ (GIRK) channels by the novel anxiolytic drug, ML297. Proc Natl Acad Sci U. S. A 111 (29), 10755-10760. [PubMed: 25002517]

24. Wen W, Wu W, Weaver CD, and Lindsley CW (2014) Discovery of potent and selective GIRK1/2 modulators via 'molecular switches' within a series of 1-(3-cyclopropyl-1-phenyl-1H-pyrazol-5yl)ureas. Bioorg Med Chem Lett. 24 (21), 5102-5106. [PubMed: 25264075]

25. Hunt SP, and Mantyh PW (2001) The molecular dynamics of pain control. Nat. Rev. Neurosci 2, 83-91. [PubMed: 11252998]

26. McMahon S, Koltzenburg M, Tracey I, and Turk D (2013) Wall \& Melzack's Textbook of Pain. 6th ed.

27. Jones CK, Eberle EL, Peters SC, Monn JA, and Shannon HE (2005) Analgesic effects of the selective group II (mGlu2/3) metabotropic glutamate receptor agonists LY379268 and LY389795 in persistent and inflammatory pain models after acute and repeated dosing. Neuropharmacology 49, 206-218. [PubMed: 15998527]

28. Ramos-Hunter SJ, Engers DW, Kaufmann K, Du Y, Lindsley CW, Weaver CD, and Sulikowski GA (2013) Discovery and SAR of a novel series of GIRK1/2 and GIRK1/4 activators. Bioorg Med Chem Lett. 23 (18), 5195-5198. [PubMed: 23916258]

29. Wen W, Wu W, Romaine IM, Kaufmann K, Du Y, Sulikowski GA, Weaver CD, and Lindsley CW (2013) Discovery of 'molecular switches' within a GIRK activator scaffold that afford selective GIRK inhibitors. Bioorg Med Chem Lett. 23 (16), 4562-4566. [PubMed: 23838260]

30. Huang Y, Zhang Y, Kong S, Zang K, Jiang S, Wan L, Chen L, Wang G, Jiang M, Wang X, Hu J, and Wang Y (2018) GIRK1-mediated inwardly rectifying potassium current suppresses the epileptiform burst activities and the potential antiepileptic effect of ML297. Biomed Pharmacother. 101, 362-370. [PubMed: 29499411]

31. Nimitvilai S, Lopez MF, Mulholland PJ, and Woodward JJ (2017) Ethanol Dependence Abolishes Monoamine and GIRK (Kir3) Channel Inhibition of Orbitofrontal Cortex Excitability. Neuropsychopharmacology 42, 1800-1812. [PubMed: 28139680]

32. Irwin S (1968) Comprehensive observational assessment: Ia. A systematic, quantitative procedure for assessing the behavioral and physiologic state of the mouse. Psychopharmacologia 3 (13), $222-$ 2257.

33. Bubser M, Bridges TM, Dencker D, Gould RW, Grannan M, Noetzel MJ, Lamsal A, Niswender CM, Daniels JS, Poslusney MS, Melancon BJ, Tarr JC, Byers FW, Wess J, Duggan ME, Dunlop J. Wood MW, Brandon NJ, Wood MR, Lindsley CW, Conn PJ, and Jones CK (2014) Selective activation of M4 muscarinic acetylcholine receptors reverses MK-801-induced behavioral impairments and enhances associative learning in rodents. ACS Chem Neurosci. 5 (10), 920-942. [PubMed: 25137629]

34. Straub W (1911) Eine empfindliche biologische reaktion auf morphin. Dtsch. Mediz. Woch 37(1911), 1426.

35. Frigeni V, Bruno F, Carenzi A, Racagni G, and Santini V (1978) Analgesia and motor activity elicited by morphine and enkephalins in two inbred strains of mice. J Pharm Pharmacol. 30 (1), 310-311. [PubMed: 26746]

36. Torrecilla M, Marker CL, Cintora SC, Stoffel M, Williams JT, and Wickman K (2002) G-ProteinGated Potassium Channels Containing Kir3.2 and Kir3.3 Subunits Mediate the Acute Inhibitory Effects of Opioids on Locus Ceruleus Neurons. J Neurosci. 22 (11), 4328-4334. [PubMed: 12040038] 
37. Shibata M, Ohkubo T, Takahashi H, and Inoki R (1998) Modified formalin test: characteristic biphasic pain response. Pain 38 (3), 347-352.

38. Wheeler-Aceto H, Porreca F, and Cowan A (1990) The rat paw formalin test: comparison of noxious agents. Pain 40 (2), 229-238. [PubMed: 2308768]

39. Tjølsen A, Berge OG, Hunskaar S, Rosland JH, and Hole K (1992) The formalin test: an evaluation of the method. Pain 51 (1), 5-17. [PubMed: 1454405]

40. Woolf C, and Mannion CJ, (1999) Neuropathic pain: aetiology, symptoms, mechanisms, and management. Lancet 5 (353), 1959-1964. 


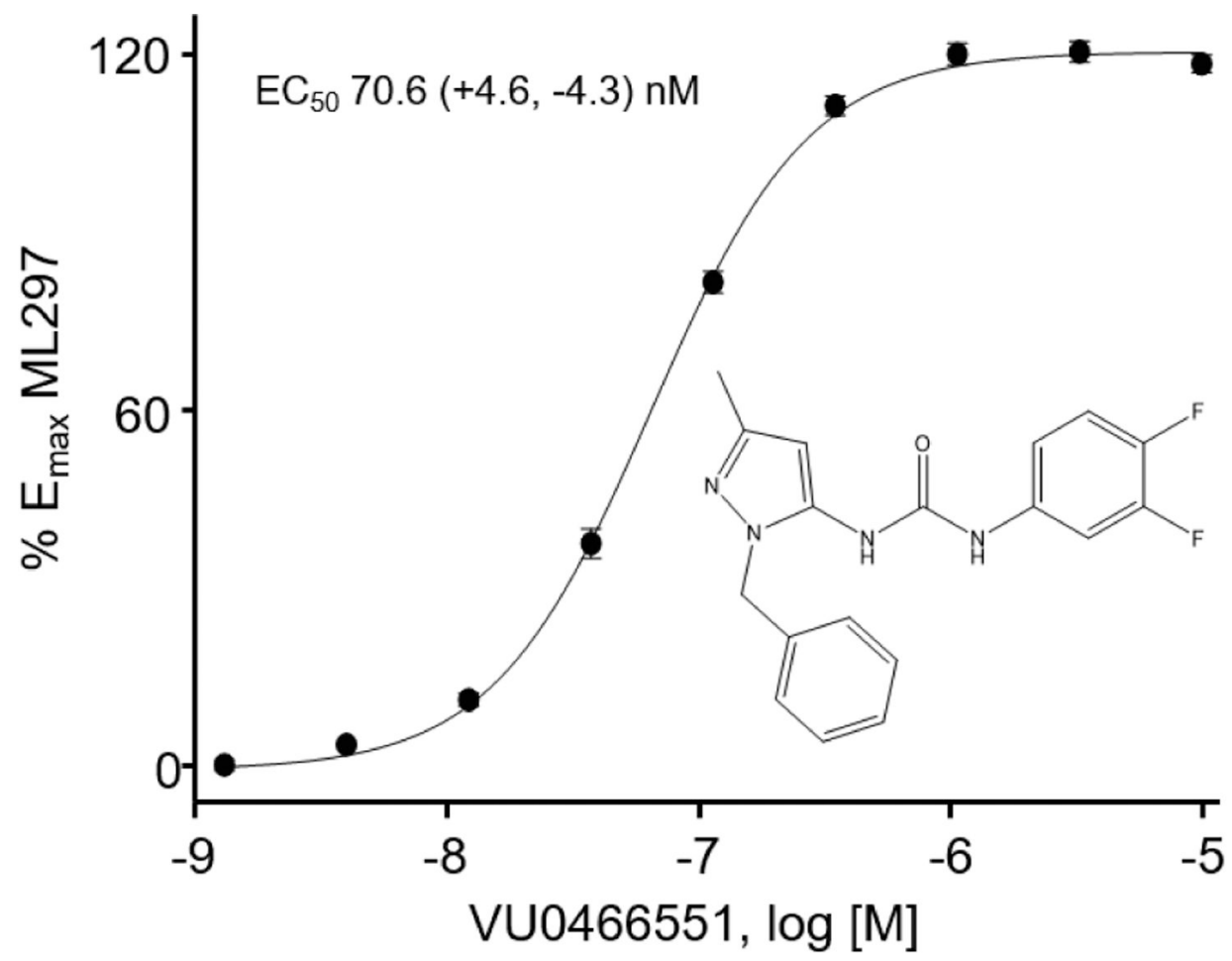

Figure 1. Concentration-dependent efficacy of VU0466551.

Shown are the concentration-dependent effects of VU0466551 (inset) on GIRK1 + GIRK2 expressed in HEK293 cells as measured using fluorescence-based $\mathrm{Tl}^{+}$flux assay. $\mathrm{N}=8$ independent determinations. The error bars depicted the standard error of the mean (SEM). The potency range expressed is the $95 \%$ confidence interval for the fit to the data. The efficacy values are normalized to a maximally effective concentration of ML297. 
$\Delta$ Vehicle s.c. + Vehicle i.p.

v Vehicle s.c. + VU551 $30 \mathrm{mg} / \mathrm{kg}$ i.p.

Morphine s.c. + Vehicle i.p. $\left(E D_{50}=18.3 \mathrm{mg} / \mathrm{kg}\right)$

- Morphine s.c. + VU551 $30 \mathrm{mg} / \mathrm{kg}$ i.p. $\left(E D_{50}=11.7 \mathrm{mg} / \mathrm{kg}\right)$

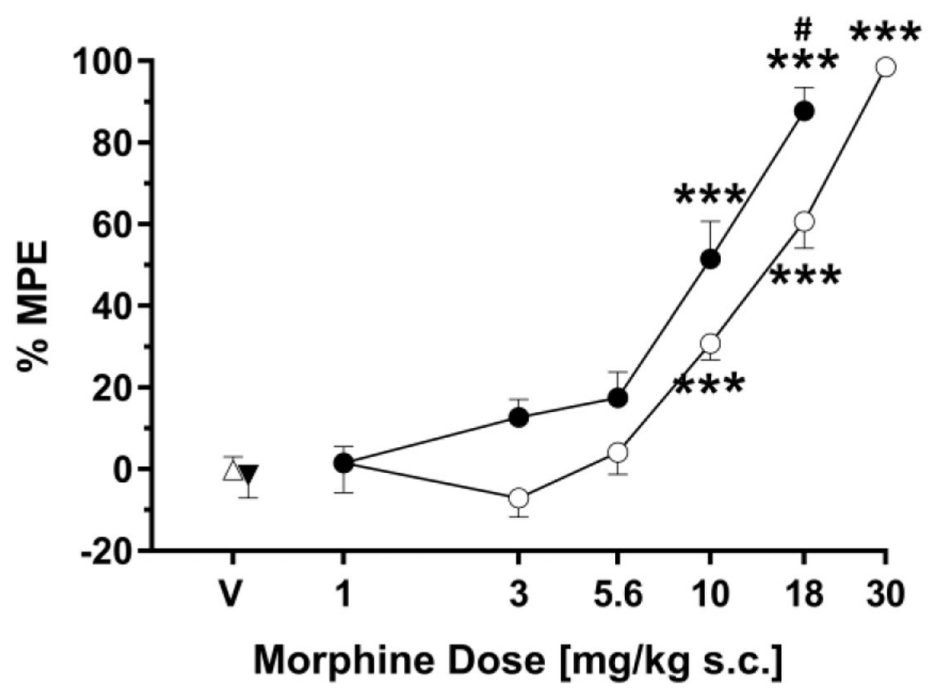

Figure 2. Analgesic efficacy of VU0466551 and morphine in the hotplate assay.

Shown are the VU0466551 (i.p.) alone, morphine (s.c.) alone, or VU0466551 plus morphine on latency of mice to respond to being placed on a $55^{\circ} \mathrm{C}$ hotplate. Data are shown are mean latencies normalized to maximum possible effect (MPE) as defined in the Methods \pm SEM for 10-12 animals per group. Asterisks (*) represent comparison of test compounds (morphine and/or VU0466551) to the vehicle + vehicle control data. Hash (\#) represent comparison of the effect of morphine + vehicle to morphine + VU0466551 ( $\leq 0.001$, ***; $\left.\mathrm{P} \leq 0.05,{ }^{\#}\right)$. 
$\triangle$ Vehicle s.c. + Vehicle i.p.

$\nabla$ Vehicle s.c. + VU0466551 i.p. $\left(\mathrm{ED}_{50}[\mathrm{mg} / \mathrm{kg}]\right.$ acute: 19.1 , chronic $\left.=20.8\right)$

Oorphine s.c. + Vehicle i.p. $\left(\mathrm{ED}_{50}[\mathrm{mg} / \mathrm{kg}]\right.$ acute: 2.75 , chronic $\left.=\mathbf{2 . 5 9}\right)$

- Morphine s.c. + VU0466551 $30 \mathrm{mg} / \mathrm{kg}$ i.p. $\left(\mathrm{ED}_{50}[\mathrm{mg} / \mathrm{kg}]\right.$ acute: 2.91 , chronic: 0.32$)$

A

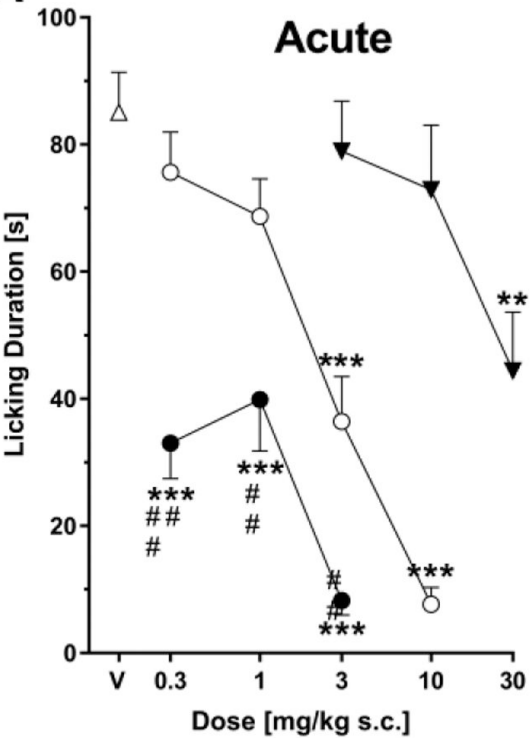

B

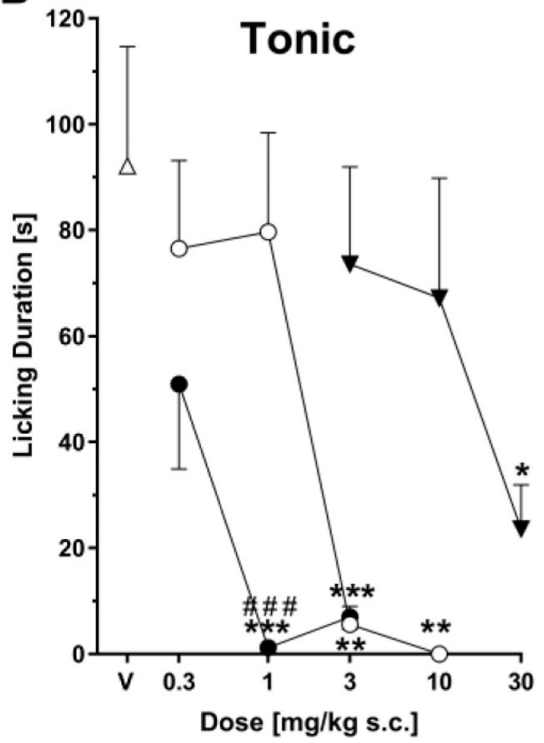

Figure 3. Efficacy of morphine and VU0466551 alone or in combination in the formalin assay. Shown are the effects in the (a) Acute phase (0-5 minutes) and (b) Tonic phase (20-30 minutes), measured $0-5 \mathrm{~min}$ and $20-30 \mathrm{~min}$ after injection of formalin, respectively. Data are shown as the duration of licking (mean \pm SEM) of 10-12 (a) and 8-14 (b) animals per group. Asterisks $(*)$ represent comparison of test compounds (morphine and/or VU0466551) to the vehicle + vehicle control data. Hash (\#) represent comparison of the effect of morphine + vehicle to morphine + VU0466551 ( $\leq 50.05$, *; $\mathrm{P} \leq 0.01$, **; $\mathrm{P} \leq 0.001$, ***; $\mathrm{P}$

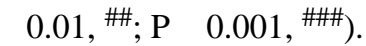

